\title{
Pengaruh Biaya Produksi, Biaya Administrasi Umum, dan Biaya Pemasaran Terhadap Laba Pada Perusahaan Food and Beverages Yang Terdaftar Di Bursa Efek Indonesia
}

\author{
Andri Hasmoro Kusumo Broto ${ }^{1}$, Rusbiyanti Sripeni ${ }^{2}$, Retno Windu Permatasari ${ }^{3}$ \\ ${ }^{1}$ Fakultas Ekonomi, Universitas Merdeka Madiun, Jl.Serayu 79, Madiun, 63133 \\ E-mail: andri@unmer-madiun.ac.id \\ ${ }^{2}$ Fakultas Ekonomi, Universitas Merdeka Madiun, Jl.Serayu 79, Madiun, 63133 \\ E-mail: rusbiyantisripeni@unmer-madiun.ac.id \\ ${ }^{3}$ Fakultas Ekonomi, Universitas Merdeka Madiun, Jl.Serayu 79, Madiun, 63133 \\ E-mail: retnowindu9@gmail.com
}

\begin{abstract}
This study aims to: (a) determine the partial effect of production costs on profits in food and beverages company listed on the Indonesia Stock Exchange. (b) To determine the effect of partial general administrative costs on profits in listed food and beverages company On the Indonesia Stock Exchange. (c) To determine the effect of partial marketing costs on profits in food and beverages company listed on the Indonesia Stock Exchange. (d) To determine the simultaneous effect of production costs, general administrative costs, and costs income to the food and beverages company listed in the Indonesia Stock Exchange. The population in this study is a food and beverages company listed on the Indonesia Stock Exchange in 2017. Data collection techniques use quarterly financial statements. Sampling purposive sampling technique. Data analysis techniques use multiple linear regression and hypothesis test ( $t$ test and $F$ test). The results show: (a) there is a partial significant negative effect on production costs on profits in the food and beverages company listed on the Indonesia Stock Exchange. (b) There is a partial significant negative effect on general administration costs on profits in the food and beverages company listed on the Indonesia Stock Exchange. (c) There is a partial significant negative effect on marketing costs on profits in the food and beverages company listed on the Indonesia Stock Exchange. (d) There is a significant negative effect simultaneously production costs, general administrative costs, and marketing costs to earnings at food and beverages company listed in Indonesia Stock Exchange.
\end{abstract}

Keywords —: Production Costs; General Administrative Costs; Marketing Costs; Profit.

\section{PENDAhuluan}

Pada era Masyarakat Ekonomi ASEAN (MEA) saat ini semakin pesatnya pertumbuhan dunia bisnis, akuntansi manajemen menjadi hal yang sangat diperlukan. Industri makanan dan minuman diproyeksikan masih menjadi salah satu sektor andalan penopang pertumbuhan manufaktur dan ekonomi nasional. Industri makanan dan minuman nasional semakin kompetitif karena jumlahnya cukup banyak. Tidak hanya meliputi perusahaan skala besar, tapi juga telah menjangkau di tingkat kabupaten untuk kelas industri kecil dan menengah. Perkembangan ekonomi yang semakin mendunia, membuat persaingan di dunia bisnis semakin tinggi dan membuat perubahan pada lingkungan bisnis. Industri makanan dan minuman merupakan sektor yang terus tumbuh dan berkontribusi besar terhadap perekonomian nasional, dan sektor ini mampu bersaing di pasar ASEAN. Indonesia memiliki jutaan ragam produk makanan dan minuman yang dapat dikategorikan sebagai specialty food. Makanan dan minuman tidak lagi hanya dilihat dari cita rasa atau harga jual. Namun latar belakang produk yang diproduksi secara etis dan bertanggungjawab semakin menjadi nilai-nilai kepantasan yang diperhitungkan pembeli maupun konsumen dalam membeli dan mengonsumsi makanan. Indonesia juga memiliki sangat banyak ragam makanan dan minuman dengan nilai budaya dan kearifan lokal yang dapat menjadi fitur terdepan produk makanan dan minuman indonesia. Namun, pada industri sektor makanan dan minuman ini memiliki sebuah tantangan yang perlu dikelola ke depan untuk semakin mendorong minat pasar dunia terhadap produk indonesia adalah peningkatan kapasitas proses produksi secara organik. Dengan kapasitas proses produksi secara organik, semakin banyak produk makanan dan minuman Indonesia yang bermutu tinggi untuk bisa diekspor atau untuk konsumsi domestik.

Dalam era MEA, manajer perusahaan harus siap bersaing dalam meningkatkan kualitas produksi, kreatifitas dan inovasi dalam mengembangkan usahanya. Apabila industri memiliki daya saing yang lemah maka akan tergeser dengan produk sejenis yang dijual dengan harga lebih murah. Manajer perusahaan juga dituntut untuk mampu meningkatkan standar, desain dan kualitas produk agar dapat diterima oleh pasar secara global.

Setiap perusahaan membutuhkan biaya administrasi umum merupakan biaya-biaya yang mengkoordinasikan kegiatankegiatan produksi dan pemasaran produk. Biaya ini juga bisa disebut sebagai biaya non produksi yang dilaporkan atau ditampilkan dalam laporan laba-rugi. Biaya administrasi umum terdiri dari gaji eksekutif dan biaya usaha umum yang secara langsung berhubungan dengan operasi umum perusahaan. 
Website : http://ekomaks.unmermadiun.ac.id/index.php/ekomaks

Setiap perusahaan membutuhkan biaya pemasaran. Dimana biaya pemasaran tersebut digunakan untuk mepromosikan produk yang akan dijual agar dikenal oleh masyarakat. Biaya pemasaran adalah biaya-biaya yang dikeluarkan sejak produk jadi dikirimkan kepada pembeli sampai produk diterima oleh pembeli. Biaya pemasaran yang dikeluarkan dituntut secara efektif dan efisien dalam menyusun strategi seperti pengeluaran biaya promosi, biaya angkut guna untuk memperoleh laba yang besar sesuai dengan target yang telah ditentukan perusahaan.

Dengan ketatnya persaingan yang terjadi antara perusahaan yang satu dengan yang lain maka akan semakin besar pula biaya pemasaran yang dikeluarkan oleh perusahaan dalam memasarkan produknya bahkan bisa melebihi biaya produksi. Biaya Produksi dalam industri merupakan bagian terbesar dari biaya yang harus dikeluarkan perusahaan. Jika informasi biaya untuk pekerjaan atau proses tersedia dengan cepat, maka manajemen mempunyai dasar yang kuat untuk merencanakan kegiatannya. Manfaat Informasi akuntasi yang dihasilkan oleh sistem dalam perusahaan akan meningkatkan kinerja manajemen dalam mencapai tujuan organisasi (Sripeni, 2012)

Perusahaan harus cermat dan rinci dalam membuat laporan keuangan terutama yang berkaitan dengan biaya produksi agar tidak terjadi penyimpangan-penyimpangan serta pemborosan biaya dalam proses produksi. Informasi harga pokok produksi dapat dijadikan titik tolak dalam menentukan harga jual yang tepat kepada konsumen dalam arti yang menguntungkan perusahaan dan menjamin kelangsungan hidup perusahaan. Setiap kegiatan perusahaan khususnya kegiatan produksi dan penjualan bertujuan untuk memperoleh laba. Ukuran yang seringkali dipakai untuk menilai berhasil atau tidaknya manajemen suatu perusahaan adalah laba yang diperoleh perusahaan. Laba terutama dipengaruhi oleh 3 faktor yaitu volume produk yang djual, harga jual produk, dan biaya. Oleh sebab itu laba merupakan tujuan utama bagi perusahaan.

Penelitian ini dilakukan di Bursa Efek Indonesia. Sektor industri food and beverages merupakan salah satu sektor usaha yang terus mengalami pertumbuhan. Seiring meningkatnya pertumbuhan jumlah penduduk di Indonesia, volume kebutuhan terhadap food and beverages pun terus meningkat. Kecenderungan masyarakat Indonesia untuk menikmati makanan ready to eat menyebabkan banyak bermunculan perusahaan-perusahaan baru di bidang makanan dan minuman. Oleh karena itu persaingan antar perusahaan pun semakin kuat. Dengan persaingan yang semakin kuat ini menuntut perusahaan untuk memperkuat fundamental agar perusahaan dapat bersaing dengan perusahaan-perusahaan lain yang sejenis. Pertumbuhan sektor industri ini lebih stabil dan tidak mudah terpengaruh oleh musim atau terjadinya perubahan kondisi perekonomian secara inflasi atau dengan kata lain, kelancaran produk perusahaan food and beverages akan tetap terjamin karena sektor ini bergerak pada bidang industri pokok manusia. Hal itu disebabkan karena kebutuhan masyarakat akan konsumsi makanan dan minuman yang tidak akan berhenti meskipun dalam kondisi apapun. Melihat kondisi ini lah maka banyak perusahaan-perusahaan yang tertarik untuk masuk ke dalam sektor food and beverages dan menjadi target yang banyak diminati oleh para investor.

\section{A. Akuntansi Biaya}

Menurut Mulyadi (2016), akuntansi biaya adalah proses pencatatan, penggolongan, peringkasan dan penyajian biaya, pembuatan dan penjualan produk atau jasa, dengan cara-cara tertentu, serta penafsiran terhadapnya. Objek kegiatan akuntansi biaya adalah biaya. Menurut Baldric dkk (2013), "Akuntansi biaya adalah proses pengukuran, penganalisisan, perhitungan, dan pelaporan biaya, profitabilitas, dan kinerja operasi untuk kepentingan internal perusahaan". Menurut Hery (2017), akuntansi biaya adalah menentukan serta menyiapkan laporan harga pokok produk.

Akuntansi biaya lebih mengarah kepada akuntansi untuk perusahaan manufaktur. Proses pencatatan, penggolongan, peringkasan dan penyajian, serta penafsiran informasi biaya adalah tergantung untuk siapa proses tersebut ditujukan. Proses akuntansi biaya dapat ditujukan untuk memenuhi kebutuhan pemakai luar perusahaan. Dalam hal ini proses akuntansi harus memperhatikan karakteristik akuntansi keuangan. Dengan demikian akuntansi biaya dapat merupakan bagian dari akuntansi keuangan.

Akuntansi biaya mempunyai tiga tujuan pokok yaitu:

1) Penentuan biaya produk

Untuk memenuhi tujuan penentuan biaya produk, akuntansi biaya mencatat, menggolongkan, dan meringkas biaya-biaya pembuatan produk atau penyerahan jasa. Biaya yang dikumpulkan dan disajikan adalah biaya yang telah terjadi dimasa yang lalu atau biaya history.

2) Pengendalian biaya

Pengendalian biaya harus didahului dengan penentuan biaya yang seharusnya dikeluarkan untuk memproduksi satu satuan produk. Jika biaya yang seharusnya ini telah ditetapkan, akuntansi biaya bertugas untuk memantau apakah pengeluaran biaya yang sesungguhnya sesuai dengan biaya yang seharusnya tersebut. Akuntansi biaya kemudian melakukan analisis terhadap penyimpangan biaya sesungguhnya dengan biaya seharusnya dan menyajikan informasi mengenai penyebab terjadinya selisih tersebut.

3) Pengambilan keputusan khusus

Pengambilan keputusan khusus menyangkut masa yang akan datang. Oleh karena itu informasi yang relevan dengan pengambilan keputusan khusus selalu berhubungan dengan informasi masa yang akan datang. Akuntansi biaya untuk mengambil keputusan khusus menyajikan biaya masa yang akan datang (future cost). 
Website : http://ekomaks.unmermadiun.ac.id/index.php/ekomaks

\section{B. Biaya}

Menurut Mulyadi (2016), biaya adalah pengorbanan sumber ekonomi, yang diukur dalam satuan uang, yang telah terjadi atau kemungkinan akan terjadi untuk tujuan tertentu. Menurut Baldric dkk (2013), biaya adalah kos barang atau jasa yang telah memberikan manfaat yang digunakan untuk memperoleh pendapatan.

\section{Penggolongan Biaya}

Beberapa pengklasifikasian biaya yang sering dilakukan menurut Mulyadi (2016) adalah pengolongan biaya atas dasar fungsi pokok dalam perusahaan. Pada perusahaan manufaktur ada tiga fungsi pokok yaitu fungsi produksi, fungsi pemasaran, dan fungsi administrasi dan umum. Oleh karena itu di dalam perusahaan manufaktur, biaya dapat dikelompokan menjadi tiga kelompok, yaitu:

1) Biaya Produksi; Biaya produksi merupakan biaya-biaya yang terjadi untuk mengolah bahan baku menjadi produk jadi yang siap dijual. Biaya ini meliputi biaya bahan baku, biaya tenaga kerja dan biaya overhead pabrik. Biaya bahan baku tersebut yang diolah dalam proses produksi. Biaya tenaga kerja langsung adalah biaya tenaga kerja yang dapat diidentifikasikan secara langsung terhadap produk tertentu. Sedangkan biaya overhead pabrik adalah biaya produksi selain biaya bahan baku dan biaya tenaga kerja langsung.

2) Biaya Pemasaran; Biaya pemasaran merupakan biaya-biaya yang terjadi untuk melaksanakan kegiatan pemasaran produk, contohnya adalah biaya iklan, biaya promosi, biaya perjalanan dinas, biaya gaji manajer pemasaran dan lain-lain. Dalam arti sempit biaya pemasaran harga meliputi biaya-biaya yang dikeluarkan sejak produk jadi dikirimkan kepada pembeli sampai produk diterima oleh pembeli. Sedangkan dalam arti luas biaya pemasaran tidak hanya meliputi biaya penjualan saja, tetapi termasuk didalamnya biaya advertising, biaya pergudangan, biaya pembungkusan dan pengiriman, biaya kredit dan penagihan, dan biaya akuntansi pemasaran.

3) Biaya Administrasi dan Umum; merupakan biaya untuk mengkoordinasikan kegiatan produksi dan kegiatan pemasaran produk. Contoh biaya ini adalah biaya gaji karyawan bagian keuangan, akuntansi, personalia dan bagian hubungan masyarakat, biaya pemeriksaan akuntan, biaya fotokopi.

\section{Laba}

Menurut Prastowo (2011), laba adalah selisih antara total penghasilan (revenue) dan beban (expense). Tujuan utama perusahaan adalah memaksimalkan laba. Pengertian laba secara operasional merupakan perbedaan antara pendapatan yang direalisasi yang timbul dari transaksi selama satu periode dengan biaya yang berkaitan dengan biaya tersebut. Menurut Hery (2017), laba adalah perubahan dalam ekuitas entitas sepanjang suatu periode sebagai akibat dari transaksi dan peristiwa serta keadaan-keadaan lainnya yang bukan bersumber dari pemilik. Laba bersih atau keuntungan bersih (net income atau net profit) merupakan kelebihan pendapatan terhadap beban-beban yang terjadi. Terdapat beberapa jenis laba yang bisa digunakan dalam akuntansi, diantaranya sebagai berikut:

1) Laba kotor merupakan hasil selisih dari hasil penjualan netto dikurangi dengan harga pokok barang yang dijual. Laba kotor merupakan perbedaan antara pendapatan bersih dari penjualan dan harga pokok penjualan;

2) Laba operasi merupakan penghasilan yang diperoleh dari penjualan hasil operasi perusahaan dalam suatu periode akuntansi tertentu dikurangi biaya operasional termasuk harga pokok barang yang dijual. Laba usaha (income from operation) adalah laba yang diperoleh semata-mata dari kegiatan utama perusahaan;

3) Laba bersih yaitu selisih lebih semua pendapatan dan keuntungan terhadap semua biaya dan kerugian, jumlah ini merupakan kenaikan bersih terhadap modal;

4) Saldo laba yaitu jumlah akumulasi laba bersih dari sebuah perseroan terbatas dikurangi distribusi laba (income distribution) yang dilakukan.

Menurut Prastowo (2011), laba merupakan empat elemen utama yaitu pendapatan (revenue), beban (expense), keuntungan (gain), dan kerugian (loss). Definisi dari elemen-elemen laba tersebut sebagai berikut:

1) Pendapatan (гелепие) adalah arus masuk atau peningkatan lain dari aktiva suatu entitas atau pelunasan kewajibannya (atau kombinasi dari keduanya) dari penyerahan atau produksi suatu barang, pemberian jasa, atau aktivitas lain yang merupakan usaha terbesar atau usaha pertama yang sedang dilakukan entitas tersebut.

2) Beban (expense) adalah arus keluar atau penggunaan lain dari aktiva atau timbulnya kewajiban (atau kombinasi keduanya) dari penyerahan atau produksi suatu barang, pemberian jasa, atau aktivitas lain yang merupakan usaha terbesar atau usaha pertama yang sedang dilakukan entitas tersebut.

3) Keuntungan (gain) adalah peningkatan dalam ekuitas atau (aktiva bersih) dari transaksi sampingan atau transaksi yang terjadi sesekali dari suatu entitas dan dari semua transaksi. Kejadian dan kondisi lainnya yang mempengaruhi entitas tersebut, kecuali yang berasal dari pendapatan atau investasi pemilik.

4) Kerugian (loss) adalah penurunan dalam ekuitas (aktiva bersih) dari transaksi sampingan atau transaksi yang terjadi sesekali dari suatu entitas dan dari semua transaksi. Kejadian dan kondisi lainnya yang mempengaruhi entitas tersebut, kecuali yang berasal dari pendapatan atau investasi pemilik. 
Website : http://ekomaks.unmermadiun.ac.id/index.php/ekomaks

\section{E. Hipotesis Penelitian}

Menurut Arikunto (2013), hipotesis adalah suatu jawaban yang bersifat sementara terhadap permasalahan penelitian sampai terbukti melalui data yang terkumpul. Berdasarkan uraian diatas, maka disusun hipotesis adalah sebagai berikut:

$\mathrm{H}_{1}$ : Ada pengaruh negatif biaya produksi secara persial terhadap laba pada perusahaan food and beverages di Bursa Efek Indonesia.

$\mathrm{H}_{2}$ : Ada pengaruh negatif biaya administrasi umum terhadap laba pada perusahaan food and beverages di Bursa Efek Indonesia.

$\mathrm{H}_{3}$ : Ada pengaruh negatif biaya pemasaran secara parsial terhadap laba pada perusahaan food and beverages di Bursa Efek Indonesia.

$\mathrm{H}_{4}$ : Ada pengaruh negatif biaya produksi, biaya pemasaran, biaya administrasi dan umum secara simultan terhadap laba pada perusahaan food and beverages di Bursa Efek Indonesia.

\section{METODE PENELITIAN}

\section{A. Jenis Penelitian}

Penelitian ini termasuk penelitian deskriptif. Penelitian kuantitatif adalah jenis penelitian yang menghasilkan penemuanpenemuan yang dapat dicapai (diperoleh) dengan menggunakan prosedur-prosedur statistik atau cara-cara lain dari kuantifikasi (pengukuran). Berdasarkan pengertian tersebut dapat dikatakan bahwa metode penelitian adalah cara yang dipergunakan untuk mengumpulkan data yang di perlukan dalam penelitian ini yang membahas tentang pengaruh biaya produksi, biaya administrasi umum dan biaya pemasaran terhadap laba pada perusahaan food and beverages yang terdaftar di Bursa Efek Indonesia tahun 2017.

\section{B. Populasi, Sampel dan Teknik Pengambilan Sampel}

Menurut Arikunto (2013), populasi adalah keseluruhan subyek penelitian. Dalam penelitian ini populasinya terdiri dari rincian data biaya produksi, biaya administrasi umum dan biaya pemasaran perusahaan food and beverages yang terdaftar di Bursa Efek Indonesia pada tahun 2017. Data diambil dari laporan keuangan dalam tahun 2017.

Menurut Sugiyono (2013), sampel adalah bagian dari jumlah dan karakteristik yang dimiliki oleh populasi tersebut. Sampel dalam penelitian ini adalah laporan tahunan (annual report) dan laporan keuangan perusahaan food and beverages yang terdaftar di Bursa Efek Indonesia pada tahun 2017. Perusahaan food and beverages yang terdaftar di BEI ada 14 perusahaan.

Teknik sampling merupakan teknik pengambilan sampel. Teknik sampling penelitian ini dilakukan dengan menggunakan metode purposive sampling. Menurut Sugiyono (2013), Purposive sampling adalah teknik penentuan sampel dengan pertimbangan tertentu. Kriteria data yang digunakan dalam penelitian ini adalah sebagai berikut :

1) Perusahaan food and beverages yang terdaftar di Bursa Efek Indonesia (BEI) pada tahun 2017.

2) Perusahaan yang menerbitkan laporan keuangan dalam bentuk triwulan yang berakhir pada tanggal 31 Desember selama periode pengamatan tahun 2017.

Dari 14 perusahaan yang terdaftar di Bursa Efek Indonesia pada tahun 2017, yang aktif menerbitkan pelaporan keuangan dalam bentuk triwulan hanya 10 perusahaan.

\section{III.HASIL DAN PEMBAHASAN}

Analisis regresi linier berganda dilakukan untuk menguji hipotesis dari data yang diperoleh, yaitu (1) data tentang laba pada Perusahaan food and beverages yang terdaftar di Bursa Efek Indonesia tahun 2017; (2) data tentang biaya produksi; (3) data tentang biaya administrasi umum dan (4) data tentang biaya pemasaran, dan diolah menggunakan program SPSS versi 16.0 .

Tabel 1

Persamaan Regresi

\begin{tabular}{|c|c|c|c|c|c|c|}
\hline & \multirow[t]{2}{*}{ Model } & \multicolumn{2}{|c|}{ Unstandardized Coefficients } & \multirow[t]{2}{*}{$\begin{array}{c}\text { Standardized } \\
\text { Coefficients }\end{array}$} & \multirow{2}{*}{$\mathbf{t}$} & \multirow[t]{2}{*}{ Sig } \\
\hline & & B & Std. Error & & & \\
\hline 1 & $\begin{array}{l}\text { (Constant) } \\
\text { biaya produksi } \\
\text { biaya administrasi umum } \\
\text { biaya pemasaran }\end{array}$ & $\begin{array}{r}-4.259 \\
-.387 \\
-.734 \\
-.378\end{array}$ & $\begin{array}{l}.270 \\
.098 \\
.227 \\
.176\end{array}$ & $\begin{array}{l}-.469 \\
-.366 \\
-.239\end{array}$ & $\begin{array}{r}-15.790 \\
-3.955 \\
-3.230 \\
-2.142\end{array}$ & $\begin{array}{l}.000 \\
.000 \\
.003 \\
.039\end{array}$ \\
\hline
\end{tabular}

a. Dependent Variable: laba

Berdasarkan Tabel 1, maka model persamaan regresi linier yang dihasilkan dalam penelitian ini adalah:

$\mathrm{Y}=-4,259+(-0,387) \mathrm{X}_{1}+(-0,734) \mathrm{X}_{2}+(-0,378) \mathrm{X}_{3}+\mathrm{e}$

1) Nilai konstanta sebesar $-4,259$ menunjukkan bahwa apabila variabel biaya produksi $\left(X_{1}\right)$, variabel biaya administrasi umum

$\left(\mathrm{X}_{2}\right)$ dan variabel biaya pemasaran $\left(\mathrm{X}_{3}\right)$ diabaikan dalam analisis, maka laba pada perusahaan food and beverages yang terdaftar di Bursa Efek Indonesia (Y) sebesar -4,259. 
2) Koefisien regresi variabel biaya produksi $\left(X_{1}\right)$ diketahui sebesar $-0,387$ artinya apabila biaya produksi meningkat 1 satuan maka laba pada perusahaan food and beverages yang terdaftar di Bursa Efek Indonesia menurun sebesar -0,387 dengan catatan variabel variabel $\mathrm{X}_{2}$ dan $\mathrm{X}_{3}$ tetap.

3) Koefisien regresi variabel biaya administrasi umum $\left(X_{2}\right)$ diketahui sebesar -0,734 artinya apabila biaya administrasi umum naik 1 satuan maka laba pada perusahaan food and beverages yang terdaftar di Bursa Efek Indonesia menurun sebesar 0,734 dengan catatan variabel variabel $\mathrm{X}_{1}$ dan $\mathrm{X}_{3}$ tetap.

4) Koefisien regresi variabel biaya pemasaran $\left(X_{3}\right)$ diketahui sebesar $-0,378$ artinya apabila kebijakan biaya pemasaran naik 1 satuan maka laba pada perusahaan food and beverages yang terdaftar di Bursa Efek Indonesia menurun sebesar - 0,378 dengan catatan variabel variabel $\mathrm{X}_{1}$ dan $\mathrm{X}_{2}$ tetap.

\section{A. Uji Parsial (Uji t)}

Uji statistik t dalam penelitian ini digunakan untuk mengetahui apakah variabel biaya produksi, biaya administrasi umum, dan biaya pemasaran secara parsial berpengaruh terhadap variabel laba. Hasil data diolah melalui SPSS 16 dapat dilihat dalam uraian sebagai berikut :

1) Pengaruh antara biaya produksi $\left(\mathrm{X}_{1}\right)$ terhadap laba $(\mathrm{Y})$

Variabel biaya produksi berpengaruh secara parsial terhadap laba pada perusahaan food and beverages yang terdaftar di Bursa Efek Indonesia. Hal ini dapat dilihat dari $\mathrm{t}_{\text {hitung }}=-3,955<\mathrm{t}_{\text {tabel }}=-2,028$ dengan tingkat probabilitas $/$ signifikansi 0,000 .

2) Pengaruh biaya administrasi umum $\left(\mathrm{X}_{2}\right)$ terhadap laba $(\mathrm{Y})$

Variabel biaya administrasi umum berpengaruh secara parsial terhadap laba pada perusahaan food and beverages yang terdaftar di Bursa Efek Indonesia. Hal ini dapat dilihat dari $t_{\text {hitung }}=-3,230<t_{\text {tabel }}=-2,028$ dengan tingkat probabilitas $/$ signifikansi 0,003 .

3) Pengaruh biaya pemasaran $\left(\mathrm{X}_{3}\right)$ terhadap laba $(\mathrm{Y})$

Variabel biaya pemasaran umum berpengaruh secara parsial terhadap laba pada perusahaan food and beverages yang terdaftar di Bursa Efek Indonesia. Hal ini dapat dilihat dari $\mathrm{t}_{\text {hitung }}=-2,142<\mathrm{t}_{\text {tabel }}=-2,028$ dengan tingkat probabilitas $/$ signifikansi 0,039.

\section{B. Uji Simultan (Uji F)}

Tabel 2

Uji F-statistik

\begin{tabular}{|c|c|c|c|c|c|c|}
\hline & Model & Sum of Squares & Df & Mean Square & $\mathbf{F}$ & Sig. \\
\hline \multirow[t]{3}{*}{1} & Regression & 6.360 & 3 & 2.120 & 17.630 & $.000^{\mathrm{a}}$ \\
\hline & Residual & 4.329 & 36 & .120 & & \\
\hline & Total & 10.688 & 39 & & & \\
\hline
\end{tabular}

a. Predictors: (Constant), biaya pemasaran, biaya administrasi umum, biaya produksi

b. Dependent Variable: laba

Berdasarkan tabel di atas dapat dijelaskan analisa data sebagai berikut: Nilai $F_{\text {hitung }}=17,630>F_{\text {tabel }}=2,242$ pada derajat keyakinan 95\%. Hasil ini menunjukkan bahwa variabel biaya produksi $\left(\mathrm{X}_{1}\right)$, biaya administrasi umum $\left(\mathrm{X}_{2}\right)$ dan biaya pemasaran $\left(\mathrm{X}_{3}\right)$ secara simultan berpengaruh signifikan terhadap laba pada perusahaan food and beverages yang terdaftar di Bursa Efek Indonesia.

\section{Koefisien Determinasi (R2)}

Tabel 3

Uji Koefisien Determinasi

\begin{tabular}{|l|r|r|r|}
\hline \multicolumn{1}{|c|}{ Model } & \multicolumn{1}{|c|}{ R Square } & Adjusted R Square & $\begin{array}{c}\text { Std. Error of the } \\
\text { Estimate }\end{array}$ \\
\hline 1 & $.771^{\mathrm{a}}$ & .595 & .561 \\
\hline
\end{tabular}

Berdasarkan tabel di atas, dapat dijelaskan bahwa nilai koefisien determinasi $\left(\mathrm{R}^{2}\right)$ yang diperoleh adalah 0,595. Artinya bahwa variasi dan ketiga variabel bebas, yaitu biaya produksi $\left(\mathrm{X}_{1}\right)$, biaya administrasi umum $\left(\mathrm{X}_{2}\right)$ dan biaya pemasaran $\left(\mathrm{X}_{3}\right)$ memberikan kontribusi pada laba pada perusahaan food and beverages yang terdaftar di Bursa Efek Indonesia sebesar 59,5\% sedangkan 40,5\% lainnya dapat dijelaskan oleh variabel lain yang tidak termasuk dalam penelitian. Misalnya harga jual, volume produk yang dijual, dan hasil penjualan. 
Website : http://ekomaks.unmermadiun.ac.id/index.php/ekomaks

\section{Pembahasan}

1) Pengaruh negatif dan signifikan secara parsial biaya produksi terhadap laba pada perusahaan food and beverages Hasil penelitian menunjukkan bahwa ada pengaruh negatif dan signifikan biaya produksi terhadap laba pada perusahaan food and beverages yang terdaftar di Bursa Efek Indonesia. Dilihat dari hasil perhitungan maka diperoleh nilai $t_{\text {hitung }}$ sebesar -3.955 sedangkan nilai signifikan sebesar 0.000 dibawah signifikan 0.05.

2) Pengaruh negatif dan signifikan secara parsial biaya administrasi umum terhadap laba pada perusahaan food and beverages Hasil penelitian menunjukkan ada pengaruh negatif dan signifikan antara biaya administrasi umum terhadap laba pada perusahaan food and beverages yang terdaftar di Bursa Efek Indonesia. Dilihat dari hasil perhitungan maka diperoleh nilai $\mathrm{t}_{\text {hitung }}$ sebesar -3,230 dan tingkat signifikan sebesar 0.003 dibawah signifikan 0.05.

3) Pengaruh negatif dan signifikan secara parsial biaya pemasaran terhadap laba pada perusahaan food and beverages Hasil penelitian menunjukkan ada pengaruh negatif dan signifikan antara biaya pemasaran terhadap laba membeli pada perusahaan food and beverages yang terdaftar di Bursa Efek Indonesia. Dilihat dari perhitungan maka diperoleh nilai $\mathrm{t}_{\text {hitung }}$ sebesar -2.142 dengan nilai signifikan sebesar 0.039 dibawah signifikan 0.05.

4) Pengaruh Negatif Dan Signifikan Secara Simultan Biaya Produksi, Biaya Administrasi Umum Dan Biaya Pemasaran Terhadap Laba pada Perusahaan Food and beverages

Hasil yang diperoleh menunjukkan ada pengaruh secara simultan antara biaya produksi, biaya administrasi umum dan biaya pemasaran terhadap laba pada perusahaan food and beverages yang terdaftar di Bursa Efek Indonesia. Dengan hasil penelitian menunjukkan (a) setelah dilakukan perhitungan maka diperoleh nilai $t_{\text {hitung }}$ sebesar -3.955 sedangkan nilai signifikan 0.000 dibawah signifikan 0.05. Hal ini menunujukkan bahwa variabel biaya produksi berpengaruh negatif signifikan terhadap laba pada perusahaan food and beverages yang terdaftar di bursa efek indonesia tahun 2017. (b) nilai $\mathrm{t}_{\text {hitung }}$ sebesar -3.230 dan nilai signifikan sebesar 0.003 dibawah signifikan 0.05. Hal ini menunjukkan bahwa variabel biaya administrasi umum berpengaruh negatif signifikan terhadap laba pada perusahaan food and beverages yang terdaftar di bursa efek indonesia tahun 2017. (c) nilai $t_{\text {hitung }}$ sebesar -2.142 dan nilai signifikan sebesar 0.039 dibawah signifikan 0.05 . Hal ini menunjukkan bahwa variabel biaya pemasaran berpengaruh negatif signifikan terhadap laba pada perusahaan food and beverages yang terdaftar di bursa efek indonesia tahun 2017. (d) berdasarkan hasil uji statistik F dapat diperoleh nilai $\mathrm{F}_{\text {hitung }}$ sebesar 17,630 dan signifikan pada variabel biaya produksi, biaya administrasi umum, dan biaya pemasaran secara bersama-sama mempengaruhi variabel laba.

\section{IV.KESIMPULAN}

1) Ada pengaruh negatif secara parsial biaya produksi terhadap laba pada perusahaan food and beverages yang terdaftar Di Bursa Efek Indonesia.

2) Ada pengaruh negatif secara parsial biaya administrasi umum terhadap laba pada perusahaan food and beverages yang terdaftar di Bursa Efek Indonesia.

3) Ada pengaruh negatif secara parsial biaya pemasaran terhadap laba pada perusahaan food and beverages yang terdaftar di Bursa Efek Indonesia.

4) Ada pengaruh negatif secara simultan biaya produksi, biaya administrasi umum, dan biaya pemasaran terhadap laba pada perusahaan food and beverages yang terdaftar di Bursa Efek Indonesia.

Berdasarkan hasil pembahasan dan kesimpulan yang diperoleh, maka disampaikan saran bahwa besarnya biaya produksi, biaya administrasi umum, dan biaya pemasaran sangat mempengaruhi tingkat pencapaian laba bersih, sebaiknya perseroan harus terus berupaya untuk meminimalkan biaya produksi, biaya administrasi umum, dan biaya pemasaran seefisien mungkin dengan tujuan untuk meningkatkan pencapaian laba bersih yang maksimal, karena laba merupakan hal pokok bagi perusahaan untuk mempertahankan kelangsungan hidup perusahan di tengah persaingan seperti sekarang ini.

\section{DAFTAR PUSTAKA}

Arikunto. 2013. Prosedur Penelitian Suatu Pendekatan Praktik. Rineka Cipta, Jakarta

Baldric, S., Bambang, S., Dody, H., Eko W. L., Erlina, H., Lita, K., Nurofik . 2013. Akuntansi Biaya. Edisi Kedua. Salemba Empat, Jakarta.

Bursa Efek Indonesia. https://www.idx.co.id//strukturorganisasi diakses pada tanggal 25 Juli 2018 pukul 08.00

Hery, S.E., M.Si., CRP., RSA. 2017. Analisis Laporan Keuangan. PT Grasindo, Jakarta.

Mulyadi. 2016. Akuntansi Biaya. Edisi ke-5. Cetakan Kesebelas. STIM YKPN, Yogyakarta.

Prastowo. 2011. Analisis Laporan Keuangan. Edisi lima. Yogyakarta.

Sripeni, Rusbiyanti. 2012. Manfaat Informasi Akuntansi dan Kontribusinya Terhadap Kinerja Manajer pada Perum Perhutani KPH Madiun. Jurnal Ekomaks: Vol. 1 No. 2 September 2012 (Hal. 54-64).

Sugiyono. 2013. Metode Penelitian. CV. Alfabeta, Bandung. 